\title{
Venous System Endothelium
}

National Cancer Institute

\section{Source}

National Cancer Institute. Venous System Endothelium. NCI Thesaurus. Code C49320.

The layer of cells that line the lumen of any vessels that is part of the venous system. 